\title{
Physicochemical properties and antioxidant activities of Streptococcus thermophilus KCCM 3782 strain fermented Cordyceps militaris grown on Tenebrio molitor
}

\author{
Do-Woo Gim ${ }^{1}$, Jun-Ki Park ${ }^{1}$, Hyun-Jin Kim², In-Kyung Cho ${ }^{3}$, Ja-Yong Cho \\ Yong-Doo Kim ${ }^{1}$, Chang-Ki Huh ${ }^{1 *}$ \\ ${ }^{1}$ Department of Food Science and Technology, Sunchon National University, Suncheon 57922, Korea \\ ${ }^{2}$ Insects and Sericultural Research Institute, Jeollanamdo Agricultural Research and Extention Services, \\ Jangseong 57214, Korea \\ ${ }^{3}$ Department of Food and Nutrition, Nambu University, Gwangju 62271, Korea \\ ${ }^{4}$ Department of Food Science and Biotechnology, Jeonnam State University, Damyang 57337, Korea
}

\section{갈색거저리 동충하초의 Streptococcus thermophilus KCCM 3782 유산균 발효에 따른 물리화학적 특성과 산화방지 활성 비교}

\author{
김도우 ${ }^{1} \cdot$ 박준기 $^{1} \cdot$ 김현진 $^{2} \cdot$ 조인경 $^{3} \cdot$ 조자용 $^{4} \cdot$ 김용두 $^{1} \cdot$ 허창기 $^{1 *}$ \\ ${ }^{1}$ 순천대학교 식품공학과, ${ }^{2}$ 전남농업기술원 곤충잠업연구소, ${ }^{3}$ 남부대학교 식품영양학과, \\ ${ }^{4}$ 전남도립대학교 식품생명과학과
}

\begin{abstract}
This study aimed to provide basic evidence regarding the development of materials by analyzing the physicochemical properties and antioxidant activities of Streptococcus thermophilus KCCM 3782 strain-fermented Cordyceps militaris grown on Tenebrio molitor. Among the solvents tested, DPPH radical scavenging activity was the highest in the hot water-extracted sample after $30 \mathrm{~min}$ of extraction. Moisture content decreased, whereas crude protein and fat content increased, after lactic acid bacteria-mediated fermentation. Sodium, magnesium, calcium, and zinc contents increased, with potassium levels attaining the maximum value, whereas free amino acid content decreased after the fermentation. Among Hunter's color values, a value increased to $66.7 \rightarrow 149.92$ after fermentation, whereas the $L$ and $b$ values decreased to $15.79 \rightarrow-15.75$ and $54.45 \rightarrow 0.01$, respectively. Cordycepin content assay increased from $7.02 \mathrm{mg} \%$ to $8.66 \mathrm{mg} \%$. The DPPH free radical scavenging activity of the fermented product was $91.92 \mathrm{EDA} \%$, which was higher than that of the extract (84.69 EDA\%). The ABTS free radical scavenging and superoxide dismutase (SOD) activities were also higher in the fermented products.
\end{abstract}

Key words : Tenebrio molitor, Cordyceps militaris hot water, Streptococcus thermophilus KCCM 3782, Cordycepin, physicochemical, antioxidative

\section{서 론}

\footnotetext{
*Corresponding author. E-mail : hck1008@sunchon.ac.kr Phone : 82-61-750-3251, Fax : 82-61-750-3208

Received 8 February 2018; Revised 18 February 2018; Accepted 22 February 2018.

Copyright (c) The Korean Society of Food Preservation. All rights reserved.
}

최근 지구의 기후변화와 식량수급문제가 대두되고 있다. 그 어느 때보다 쌀, 보리, 밀, 옥수수, 감자 등의 작물의 수확량이 증가하고 있음에도 불구하고 국제 농산물 가격은 급등하고 있으며 전 세계적으로 10 명중 1 명은 끼니를 해결 하지 못하고 있는 실정이다(1). 이 같은 모순을 해결하기 위한 대안 중 하나는 단백질 공급원으로써 곤충을 활용 하는 식용곤충 분야이다. 저장 곡물의 해충으로 인류가 박 멸해야할 대상이었던 갈색거저리는 대량 사육이 쉽고, 조 
류나 파충류 등의 먹이에 유용하여 2000년대 후반부터 본 격적으로 사육 연구가 시작되었다. 2014년 농촌진흥청에서 독성검사를 통해 식용으로 활용이 가능하다고 발표하였고, 2016년에는 인체에 대한 영양성과 안전성을 규명 받아 그 결과를 바탕으로 식품의약품안전처에 식품 원료 등록 신청 을 통해 현재는 식품 원료로 인정을 받은 상황이다(2).

갈색거저리는 $44-70 \%$ 의 고단백질을 함유하고 필수아미 노산 조성이 좋은 영양원이며, 불포화지방산, 비타민 및 칼슴, 철분, 마그네숨 등의 무기질 함량이 풍부하여 미래 우수한 식량원으로 평가 받고 있다(3). 현재 갈색거저리를 활용한 제품 개발 연구로 도토리묵(4), 파스타(5), 식빵(6), 쿠키(7) 및 패티(8) 등의 연구가 진행 되었으며, 기능성 제품 개발 연구 또한 활발히 진행 중이다. 기능성에 관련된 연구 로는 갈색거저리 단백질의 항균 효과(9), 키틴합성 저해제 의 활성평가 등의 연구가 진행 되었고 $(10,11)$, 위 장관 수술 을 받은 사람에게 갈색거저리 첨가 식품이 우수한 영양원으 로 확인되었다고 보고하여 식품 신소재로서의 기대를 받고 있는 실정이다(12).

동충하초는 온습도가 높아지는 시기인 여름에 cordyceps 균이 누에, 애벌레, 풍뎅이, 나비, 번데기 등과 같은 곤충을 숙주로 삼아 발육 증식하다가 숙주를 죽이고 자실체를 형성 하는 약용버섯이다(13). 겨울에는 벌레이던 것이 여름이 되면 버섯으로 변한다고 하여 동충하초라 부르게 되었으며 (14) 전 세계적으로 약 300 여종이 분포되어 있고, 국내에서 도 76종을 채집하여 분리 동정하였다고 보고 되어있다(15). 중국의 내륙지방에서 한약재로 사용되어 졌으며 서기 1757 년 중국의 명의 오의락이 저술한 본초종신(本草從新)과 서 기 1765 년 조학민의 저서 본초강목습유(本草綱目拾遺)에서 는 심장과 폐를 튼튼히 하며 지혈에도 탁월하고 가래를 삭일 수 있다고 전해지며 효능이 인삼과 같다고 기록되어 있다 $(16,17)$. 이 외에도 신장의 강장제라고 불러질 만큼 신 장의 기능에 탁월하며, 백혈병, 비염, 기관지염, 아토피, 고 혈압, 심장병, 이명과 같은 질병에도 치료율이 높은 것으로 알려지면서(18) 동충하초를 첨가한 젤리(19), 고추장(20), 한방식초(21) 등 많은 식품에 첨가되어 건강기능성 식품으 로써 우수성을 인정받고 있다. 이러한 다양한 기능성을 갖 는 동충하초를 갈색거저리를 숙주로 활용하여 생산한 갈색 거저리 동충하초는 식품소재로써 최근 개발된 소재로 다양 한 제품 개발과 기능적 연구가 필요한 실정이다.

발효법은 역사상 가장 오래된 기술로써 식품, 약품, 화장 품 등 다양한 분야에서 활용되고 있는데 그 중 인류 역사와 함께 해온 식품 발효는 현재까지 전 세계적으로 가장 널리 이용되고 있는 기술이다. 최근에는 발효식품의 생리활성 작용이 알려지면서 세계적으로 건강기능성 장수식품으로 인식되고 있으며(22), 특히 프로바이오틱스로서 유산균의 건강기능성이 밝혀지면서 이에 대한 관심이 높다. 유산균 은 발효식품에 특유의 풍미와 우수한 보존성을 부여할 뿐만
아니라 항산화작용, 정장작용, 병원성세균의 생육억제 작 용, 콜레스테롤 저하작용, 항암작용 등 다양한 질병을 예방 하고 치료할 수 있다고 알려져 있다(23). 또한 건강한 사람 의 장내에 존재하면서 인체의 특이 및 비특이적 면역체계의 증강에 기여한다고 알려져 있으며, 최근에는 유산균 발효 에 의한 천연물의 면역증진 효과에 관한 연구가 많이 보고 되고 있다(23). 하지만 아직까지 유산균 발효기술을 이용한 갈색저거리 동충하초의 기능성에 대한 연구는 전무한 실정 이다.

이에 본 연구에서는 신규 식품소재로 부각되고 있는 갈 색저거리 동충하초를 열수 추출하고 프로바이오틱스 유산 균으로 발효 후 추출물과의 기능성을 평가하여 생리 기능성 바이오 소재 및 제품 개발을 위한 기초자료로 제공하고자 한다.

\section{재료 및 방법}

\section{실험재료}

본 연구에 사용된 갈색거저리 동충하초는 중국 산동성농 업과학원 자원 및 환경연구소에서 구입하여 이물질을 제거 하고 분쇄하여 $-50^{\circ} \mathrm{C}$ 에서 보관하면서 시료로 사용하였다.

\section{사용균주}

본 연구에 사용된 7종의 유산균주는 $\mathrm{KCCM}$ (Korean Culture Center of Microorganisms)에서 분양 받은 유산균주 (Lactobacillus bulgaricus KCCM 3635, Lactobacillrus lactis KCCM 2013, Enterococcus faecalis KCCM 3206, Streptococcus thermophilus KCCM 3782, Bifidobacterium breve $\mathrm{KCCM} 3441)$ 5종과 임실치즈앤식품연구소에서 제공 받은 김치에서 분리한 유산균주(Lactobacillus sakei ALJ 011, Pediococcus pentosaceus ALJ 016) 2종을 사용하였다.

시약 및 배지

사용 용매인 ethanol(HPLC용), acetonitrile(HPLC용) 및 methanol(HPLC용)은 J. T. Baker사(Phillipsburg, NJ, USA) 사용하였고, DPPH용액 및 potassium persulfate는 SigmaAldrich사(St. Louis, MO, USA), Folin-Ciocalteu reagent는 Millipore사(Darmstadt, Germany) 것을 구입하여 사용하였 고, $\mathrm{BCP}$ 배지는 Eiken chemical사(Tokyo, Japan) 것을 구입 하여 사용하였다.

\section{갈색거저리 동충하초 추출물 제조}

갈색거저리 동충하초 추출물은 건조된 자실체를 분쇄하 여 $30 \mathrm{~g}$ 에 10 배의 증류수를 넣고 $80^{\circ} \mathrm{C}$ 에서 30 분간 열수환류 추출한 후 추출액을 여과(Whatman No.2) 하였다. 이 추출여 액을 rotary vacuum evaporator로 $50^{\circ} \mathrm{C}$ 수욕상에서 감압 농 
축 후 증류수 $100 \mathrm{~mL}$ 로 정용하여 사용하였다.

\section{갈색거저리 동충하초 유산균 발효물 제조}

갈색거저리 동충하초 발효 우수 균 선정 분석 조건은 건조된 자실체를 분쇄하여 $30 \mathrm{~g}$ 에 10 배의 증류수를 넣고 $80^{\circ} \mathrm{C}$ 에서 30 분간 열수환류추출한 후 추출액을 여과 (Whatman No.2) 하였다. 이 추출여액에 $5 \%$ 의 sucrose를 넣고 7 종의 유산균을 각각 첨가하여 $37^{\circ} \mathrm{C}$ 로 $1,3,6,12$, 24시간 동안 배양하면서 $\mathrm{DPPH}$ 자유 라디칼 소거활성을 측정하였다. 발효물 제조는 위와 같은 방법으로 전 처리 하였으며, 배양 6시간째 항산화 활성이 가장 높게 나타난 Streptococcus thermophilus KCCM 3782 를 우수 균으로 선 정하고 $37^{\circ} \mathrm{C}$ 로 6 시간 동안 배양하였다. 배양 후 발효액을 rotary vacuum evaporator로 $50^{\circ} \mathrm{C}$ 수옥상에서 감압 농축 후 증류수 $100 \mathrm{~mL}$ 로 정용하여 사용하였다.

\section{일반성분 분석}

갈색거저리 동충하초 열수 추출물과 유산균 발효물의 일반성분 분석은 $\mathrm{AOAC}$ 표준분석법(24)에 따라 실시하였 다. 수분은 $105^{\circ} \mathrm{C}$ 상압가열건조법, 회분은 $550^{\circ} \mathrm{C}$ 회화처리, 조단백질의 함량은 Kjeldahl법, 조지방은 Soxhlet 추출법으 로 측정하였다.

\section{무기성분 분석}

본 연구의 무기성분 분석은 습식분해법(25)으로 전처리 하여 분석 하였다. 시료 $0.5 \mathrm{~mL}$ 에 진한 질산 $10 \mathrm{~mL}$ 를 가하여 heating plate에서 백연현상이 일어날 때 까지 가열 시킨 다음 질산 $0.5 \mathrm{~mL}$ 를 가한 후 증류수 $100 \mathrm{~mL}$ 로 정용하여 검액으로 하였다. 각 무기성분의 정량은 원자흡광비색계 (Perkin Elmer Analyst 300, Perkin Elmer Co., Norwalk, CT, $\mathrm{USA})$ 로 각 원소(K; $766.5 \mathrm{~nm}, \mathrm{Mg} ; 285.2 \mathrm{~nm}, \mathrm{Na} ; 589.0$ $\mathrm{nm}, \mathrm{Ca} ; 422.7 \mathrm{~nm}, \mathrm{Fe} ; 248.3 \mathrm{~nm}, \mathrm{Zn} ; 214.9 \mathrm{~nm}$ )의 표준용액 농도를 1,3 및 $5 \mathrm{ppm}$ 으로 조제하여 표준검량 곡선을 작성하 여 분석하였다.

\section{유리 아미노산 분석}

본 연구의 아미노산 분석은 Ohara와 Ariyosh의 방법 (26)으로 분석하였다. 시료 $10 \mathrm{~g}$ 에 증류수를 혼합하여 100 $\mathrm{mL}$ 로 정용한 다음, 원심분리하여 상징액 $10 \mathrm{~mL}$ 를 취해 sulfosalicylic acid $25 \mathrm{mg}$ 을 가하고 $4^{\circ} \mathrm{C}$ 에서 4 시간 동안 방치 후 원심분리 하였다. 그 상징액을 $0.45 \mu \mathrm{M}$ membrane filter로 여과한 여 액을 아미노산 자동분석기(Biochrom30+ Amino Acid Analyzer, Cambridge, UK)를 이용해 분석하였다.

\section{Cordycepin 함량분석}

시료용액의 조제는 각각의 시료 $1 \mathrm{~g}$ 과 증류수 $100 \mathrm{~mL}$ 를 넣어 $110^{\circ} \mathrm{C}$ 의 열탕 속에서 1 시간 추출하였다. 실온으로 냉
각한 후 $4,000 \mathrm{rpm}$ 에서 10 분간 원심분리 하고 그 상징액을 $0.45 \mu \mathrm{M}$ membrane filter로 여과하여 정제한 후 HPLC(1260 Series, Agilent Co., Darmstadt, Germany)로 분석하였다(27). 분석용 컬럼은 $\mathrm{C}_{18}(4.6 \times 100 \mathrm{~mm}$, Waters, Milford, MA, USA) 을 사용하였고, 이동용매는 $20 \mathrm{mM}$ potassium dihydrogen phosphate buffer $\mathrm{KH}_{2} \mathrm{PO}_{4}$ 를 사용하였으며, 이동상의 속도 는 $0.5 \mathrm{~mL} / \mathrm{min}$, 시료 주입량은 $10 \mu \mathrm{L}$ 사용하였다. 분석 온도 는 $25^{\circ} \mathrm{C}$ 를 유지하고 표준물질(cordycepin)을 시료와 동일한 조건에서 분석하여 머무름 시간을 비교해 확인하였으며, 검량곡선으로부터 그 함량을 산출하였다.

\section{색도 측정}

시료를 일정량 취해 색도계(super color sp-80, Tokyo Denshoku Co., Tokyo, Japan)를 이용해 X=80.84, $\mathrm{Y}=82.22$, $\mathrm{Z}=92.98$ 인 표준 백색판(standard white plate)으로 보정하여 사용하였다. 측정값은 명도를 나타내는 L 값(lightness), 적 색을 나타내는 a 값(redness) 및 황색을 나타내는 $\mathrm{b}$ 값 (yellowness)으로 나타내었다.

\section{1,1-Diphenyl-2-picryhydrazyl(DPPH) 자유 라디 칼 소거 활성 측정}

$\mathrm{DPPH}$ 자유 라디칼 소거활성은 Blois의 방법(28)의 방법 에 따라 시료의 1.1-diphenyl-2-picryl-hydrazyl(DPPH)에 대 한 수소공여 효과로 측정하였다. 일정 농도의 시료 $2 \mathrm{~mL}$ 에 $2 \times 10^{-4} \mathrm{M} \mathrm{DPPH}$ 용액(dissolved in $99 \%$ methanol)을 $1 \mathrm{~mL}$ 첨가하고, vortex mixing하여 $37^{\circ} \mathrm{C}$ 에서 30 분간 반응시켰다. 이 반응액을 흡수분광광도계를 사용하여 $528 \mathrm{~nm}$ 에서 흡광 도를 측정 하였다. 전자공여능(electron donating ability, $\mathrm{EDA}(\%)$ 으로 측정하였으며, 3 회 반복 실험하여 얻은 결과 를 평균과 표준편차로 나타내었다.

2-2'-Azino-bis3-ethylbenzothiazoline-6-sulph onic acid(ABTS) 자유 라디칼 소거 활성 측정

$\mathrm{ABTS}$ 자유 라디칼 소거활성은 과황산칼륨(potassium persulfate)의 반응에 의해 생성된 ABTS radical이 시료내의 항산화 물질에 의해 제거되면서 청록색으로 탈색되는 것을 이용한 방법(29)이다. $2.4 \mathrm{mM}$ potassium persulfate 용액을 $7 \mathrm{mM}$ ABTS가 되도록 용해시킨 다음 암소에서 24시간 동안 반응 시켰다. ABTS solution을 형성 시킨 후 $734 \mathrm{~nm}$ 에 서 흡광도 값이 $0.70 \pm 0.02$ 가 되게 증류수로 희석하였다. 희석된 용액과 각 추출물을 $1: 1$ 로 혼합 한 후 $734 \mathrm{~nm}$ 에서 흡광도를 측정하였다.

\section{$\mathrm{SOD}$ 활성 측정}

SOD activity는 Marklund와 marklund(30)의 방법에 따라 각 시료 $0.2 \mathrm{~mL}$ 에 tris- $\mathrm{HCl}$ 완충용액 $(50 \mathrm{mM}$ tris $+10 \mathrm{mM}$ EDTA, $\mathrm{pH} 8.5) 2.6 \mathrm{~mL}$ 와 $7.2 \mathrm{mM}$ pyrogallol $0.2 \mathrm{~mL}$ 를 가하 
여 $25^{\circ} \mathrm{C}$ 에서 10 분간 반응시킨 후 $1 \mathrm{M} \mathrm{HCl} 0.1 \mathrm{~mL}$ 를 가하여 반응을 정지시키고, 반응액 중 산화된 pyrogallol의 양을 $420 \mathrm{~nm}$ 에서 흡광도를 측정하였다.

\section{통계분석}

실험결과는 3회 반복 측정하여 SPSS program을 사용하 였고, mean $\pm \mathrm{SD}$ 을 구하였으며 Duncan's multiple range test 로 시료간의 유의차를 다중 비교법으로 분석하였다. 독립 된 두 집단의 평균값 비교는 두 표본 $\mathrm{t}$-검정(two sample t-test)을 이용하여 집단 간의 차이를 분석하였다.

\section{결과 및 고찰}

주정 농도와 추출시간에 따른 $\mathrm{DPPH}$ 자유 라디칼 소거 활성

갈색거저리 동충하초의 물과 주정 농도에 따른 추출물의 $\mathrm{DPPH}$ 자유 라디칼 소거 활성을 측정한 결과는 Fig. $1 \mathrm{~A}$ 와 같다. 추출 방법은 열수 추출과 주정 농도 $30 \%, 50 \%, 70 \%$ 및 $100 \%$ 로 환류추출 하였으며 이중 열수 추출물이 74.81 $\mathrm{EDA}$ (electron donating ability)\%로 가장 높은 활성을 보였 다. 주정 추출물의 경우 ethanol $30 \%$ 농도에서 $70.31 \mathrm{EDA} \%$ 활성을 보였고 농도가 증가할수록 활성이 낮아졌다. 천연 소재에는 다양한 기능성을 함유하고 있으며, 기능성 성분 을 추출하기 위해 여러 추출용매를 사용하게 된다(31). 하지
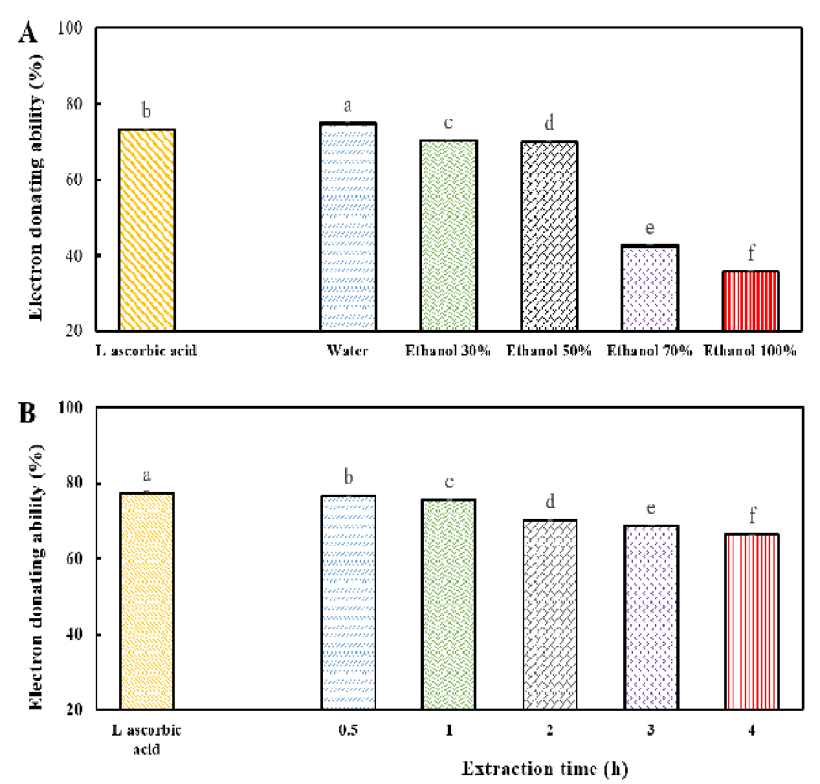

Fig. 1. DPPH free radical scavenging ability according to extraction condition of Cordyceps militaris grown upon Tenebrio molitor.

A, DPPH free radical scavenging ability of Cordyceps militaris extracts by different solvent; B, DPPH free radical scavenging ability of Cordyceps militaris water extracts by different time.

L-ascorbic acid $(10 \mathrm{ppm})$, All values are mean $\pm \mathrm{SD}$, Means in the same column followed by different uppercase letters are significantly different $(p<0.05, a>b>c>d>c>f)$.
만 식품에서는 직접 섭취를 통해 기능성 성분의 효능을 볼 수 있기 때문에 물과 주정으로 제한을 하고 있다(32). 또한 산업화 측면에서 주정을 사용할 경우 원가 상승으로 인해 사업성이 떨어지는 문제점이 있다. 따라서 위의 갈색 거저리 동충하초 항산화 활성을 측정한 결과 물 추출물에서 가장 높게 나와 식품으로써의 활용 가치가 충분할 것으로 사료된다.

갈색거저리 동충하초의 추출 시간에 따른 $\mathrm{DPPH}$ 자유 라디칼 소거 활성을 측정한 결과는 Fig. $1 \mathrm{~B}$ 와 같다. 열수 추출물과 주정 농도 $30 \%, 50 \%, 70 \%$ 및 $100 \%$ 로 추출한 추출물의 DPPH 자유 라디칼 소거 활성 측정에서 가장 높은 활성을 나타내었던 물을 용매로 하였으며 $80^{\circ} \mathrm{C}$ 에서 30 분, 1 시간, 2 시간, 3 시간 및 4 시간 동안 환류 추출 후 $\mathrm{DPPH}$ 자유 라디칼 소거 활성을 측정하였다. 30 분 추출에서 76.49 $\mathrm{EDA} \%$ 로 가장 높았으며 1시간 추출에서는 $75.43 \mathrm{EDA} \%$ 로 30 분 추출에 비해 낮은 활성을 나타내었다. 그 이후로도 2시간, 3시간 및 4시간은 66.42-70.06 EDA\% 활성을 보여 시간이 증가할수록 활성이 낮아지는 경향을 확인하였다.

유산균별 발효조건에 따른 DPPH 자유 라디칼 소거 활성 프로바이오틱스 유산균주 7종을 갈색거저리 동충하초 열수 추출물에 첨가 후 배양 시간에 따른 DPPH 자유 라디칼 소거 활성을 측정한 결과는 Fig. 2와 같다. 즉 균주 첨가 후 $37^{\circ} \mathrm{C}$ 에서 1 시간, 3 시간, 6 시간, 12 시간 및 24 시간 배양 하였을 때 $\mathrm{DPPH}$ 자유 라디칼 소거 활성을 $\mathrm{EDA} \%$ 로 표시하 였다. 배양 1 시간에서 균주를 첨가하지 않은 control군과 P. pentosaceus 접종 시료구를 제외한 모든 시료구가 75.07-79.01 EDA\%로 control군의 $71.62 \mathrm{EDA} \%$ 보다 높은 활성을 나타내었다. 배양 6시간에서는 L. sakei 첨가 시료구 가 $72.69 \mathrm{EDA} \%$ 로 배양 1시간째인 $79.01 \mathrm{EDA} \%$ 보다 활성 이 낮아지는 것을 확인 하였으나 control군을 제외한 모든 시료구가 73.20-80.01 EDA\%로 1시간 배양보다 높아진 것 을 확인 할 수 있었다. 배양 12 시간, 24 시간에서는 6 시간에 비해 상대적으로 활성이 높아진 시료구도 있었으나 전체적 으로 발효 시간이 6시간을 초과하였을 때 활성이 낮아지는 것을 확인 하였다. 배양 조건으로 설정한 7가지 프로바이오 틱스 유산균주 첨가 후 1시간, 3시간, 6시간, 12시간 및 24시간 동안 배양한 결과 배양 6시간째 $S$. thermophilus 균주 가 $80.01 \mathrm{EDA} \%$ 로 가장 높게 나타났으며, $\mathrm{Ahn}(33)$ 등의 보고에 의하면 갈색거저리 동충하초의 지표물질인 cordycepin의 함량과 균주를 통한 발효가 항산화 활성의 증가와 상관관계가 있다고 보고하였다. 본 연구에서 사용 된 갈색거저리 동충하초 열수 추출물의 추출수율은 $28.1 \%$ 로 나타났으며 7가지 균주를 첨가하였을 때 S. thermophilus 균주가 다른 균주에 비하여 항산화 활성이 우수하다고 판 단되어 갈색거저리 동충하초 발효 우수 균주로 최종 선정 하였다. 


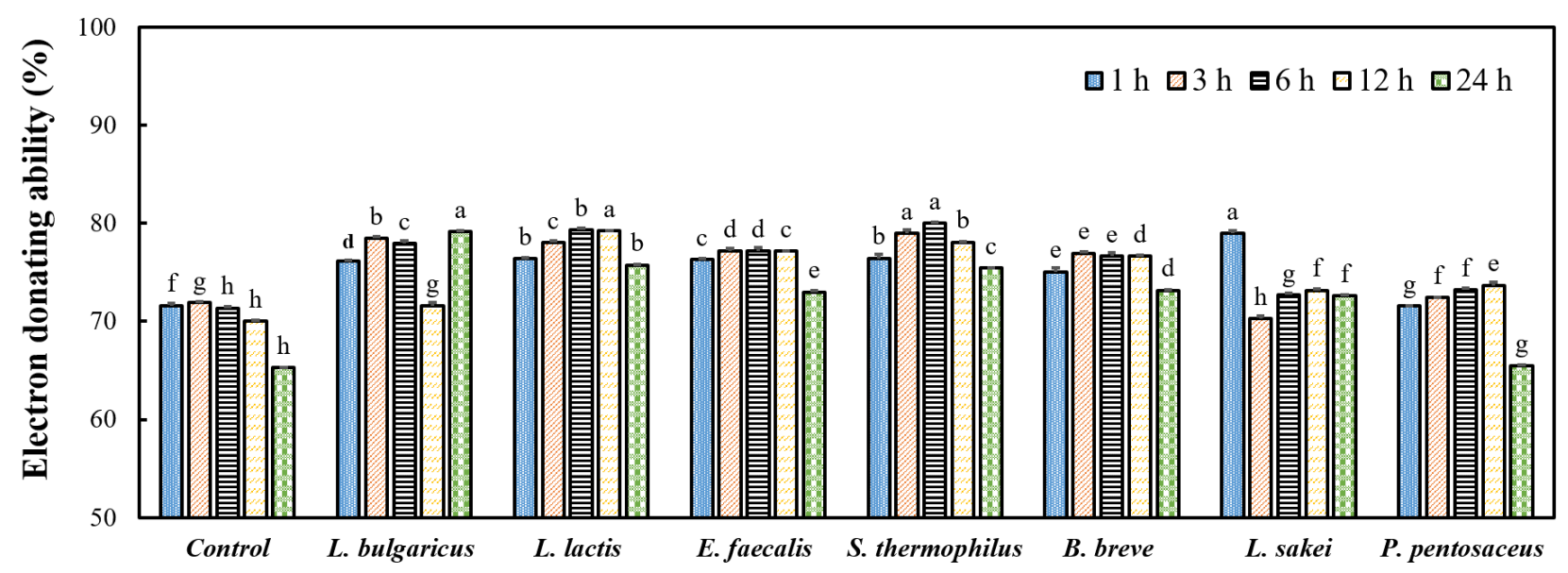

Fig. 2. DPPH free radical scavenging ability of fermented $C$. militaris water extracts during fermentation time with various lactic acid bacteria strains.

All values are mean \pm SD.

Means in the same column followed by different uppercase letters are significantly different $(\mathrm{p}<0.05, \mathrm{a}>\mathrm{b}>\mathrm{c}>\mathrm{d}>\mathrm{e}>\mathrm{f}>\mathrm{g}>\mathrm{h})$.

\section{일반성분}

갈색거저리 동충하초 물 추출물과 유산균 발효물의 일반 성분 함량을 측정한 결과는 Table 1 과 같다. 측정 결과 수분 은 물 추출물, 유산균 발효물 각각 $85.27 \%, 68.54 \%$, 조단백 질 $2.97 \%, 3.56 \%$, 조지방 $0.32 \%, 1.06 \%$, 조회분 $0.06 \%$, $0.06 \%$ 의 함량을 보였다. Choi(34)는 녹차의 발효정도에 따 라 조단백질 함량이 $37.31 \%$ 에서 $40.25 \%$ 로 증가하였고 조 지방의 함량도 $2.25 \%$ 에서 $2.84 \%$ 로 증가하였으며 수분과 조회분의 함량은 변화가 없다고 보고하였다. 본 연구의 조 단백질, 조지방 및 조회분 함량의 변화는 Choi(34)의 보고와 유사한 경향을 나타내었으나 발효물의 수분은 물 추출물에 비해 더 낮게 나타났다. 이는 발효물 제조시 당의 첨가에 의한 차이로 사료된다.

Table 1. Proximate composition according to lactic acid bacteria fermentation of $C$. militaris grown upon $T$. molitor

\begin{tabular}{ccccc}
\hline Composition & $\mathrm{NP}^{1)}$ & $\mathrm{FP}$ & \multicolumn{1}{c}{ T-value } & P-value \\
\hline Moisture & $85.27 \pm 0.02^{2)}$ & $68.54 \pm 0.09$ & $308.903^{* * * 3)}$ & 0.000 \\
Crude protein & $2.97 \pm 0.04$ & $3.56 \pm 0.18$ & $-5.480^{* *}$ & 0.026 \\
Crude fat & $0.32 \pm 0.04$ & $1.06 \pm 0.06$ & $-17.308^{* * * *}$ & 0.000 \\
Crude ash & $0.06 \pm 0.00$ & $0.06 \pm 0.01$ & -1.789 & 0.215 \\
\hline
\end{tabular}

${ }^{1)} \mathrm{NP}$, non-fermented product; FP, fermented product.

${ }^{2)}$ All values are mean $\pm \mathrm{SD}$.

${ }^{3)^{* *}} \mathrm{p}<0.05, \quad{ }^{* * * * *} \mathrm{p}<0.005$.

\section{무기성분}

갈색거저리 동충하초 물 추출물과 유산균 발효물의 무기 성분은 potassium, sodium, magnesium, calcium, zinc을 분석
하였으며 그 결과는 Table 2 와 같다. 무기성분 조성 중 potassium의 함량이 물 추출물 $5.75 \mathrm{mg} \%$, 유산균 발효물 $5.92 \mathrm{mg} \%$ 로 가장 높게 나타났으며 물 추출물의 경우 magnesium $0.90 \mathrm{mg} \%$, sodium $0.86 \mathrm{mg} \%$, zinc $0.05 \mathrm{mg} \%$, calcium $0.03 \mathrm{mg} \%$ 순으로 높게 나타났으나 유산균 발효물 의 경우 sodium $1.69 \mathrm{mg} \%$, magnesium $1.00 \mathrm{mg} \%$, calcium $0.31 \mathrm{mg} \%$, zinc $0.07 \mathrm{mg} \%$ 순으로 높게 나타났다. $\operatorname{Kim}(35)$ 은 백련잎차의 무기성분을 분석한 결과 동충하초 균사체로 백련잎차를 발효시킨 경우 발효시키지 않은 백련잎차보다 potassium, magnesium, calcium의 함량이 높게 나타나 본 연구와 일치하는 경향을 나타내었다.

Table 2. Contents of minerals according to lactic acid bacteria fermentation of $C$. militaris grown upon $T$. molitor

\begin{tabular}{ccccc}
\hline & & & & $(\mathrm{mg} \%)$ \\
\hline Components & $\mathrm{NP}^{1)}$ & $\mathrm{FP}$ & T-value & P-value \\
\hline $\mathrm{K}$ & $5.75 \pm 0.11^{2)}$ & $5.92 \pm 0.07$ & $-2.205^{* 3)}$ & 0.092 \\
$\mathrm{Na}$ & $0.86 \pm 0.02$ & $1.69 \pm 0.00$ & $-71.880^{* * * *}$ & 0.000 \\
$\mathrm{Mg}$ & $0.90 \pm 0.00$ & $1.00 \pm 0.00$ & $-4)$ & - \\
$\mathrm{Ca}$ & $0.03 \pm 0.00$ & $0.31 \pm 0.00$ & - & - \\
$\mathrm{Zn}$ & $0.05 \pm 0.01$ & $0.07 \pm 0.00$ & $-3.978^{* *}$ & 0.016 \\
\hline
\end{tabular}

${ }^{1)} \mathrm{NP}$, non-fermented product; FP, fermented product.

${ }^{2)}$ All values are mean $\pm \mathrm{SD}$.

3) ${ }^{*}<<0.1, \quad{ }^{* *} \mathrm{p}<0.05,{ }^{* * * *} \mathrm{p}<0.005$.

${ }^{4}$ Not significant different.

유리 아미노산

갈색거저리 동충하초 물 추출물과 유산균 발효물의 유리 아미노산을 분석한 결과는 Table 3 과 같다. 총 유리아미노 
산 함량은 물 추출물 $10,221.02 \mathrm{mg} \%$, 유산균 발효물 $9,458.66 \mathrm{mg} \%$ 로 물 추출물의 함량이 더 높게 나타났다. 필수아미노산은 8 종이 검출되었으며 8 종의 함량은 물 추출 물 2,714.64 $\mathrm{mg} \%$, 유산균 발효물 2,581.85 $\mathrm{mg} \%$ 로 필수아미 노산 또한 물 추출물의 함량이 더 높게 나타났다. 아미노산 종류에 따른 함량을 비교해 보면 glutamic acid의 함량이 $2,059.97 \mathrm{mg} \%$ 로 물 추출물이 가장 높은 함량을 나타내었고 유산균 발효물이 $1,922.64 \mathrm{mg} \%$ 로 나타났다. 그 외에 물 추출물은 aspartic acid, alanine 순으로 높게 나타났으며 유 산균 발효물은 alanine, aspartic acid 순으로 높게 나타났다. 필수아미노산 8 종의 경우 물 추출물은 threonine의 함량이 $644.04 \mathrm{mg} \%$ 로 가장 높았으며 lysine, valine 순으로 높았다. 유산균 발효물의 경우 lysine이 $621.15 \mathrm{mg} \%$ 의 함량으로 가장 높게 나타났으며 threonine, valine 순으로 높게 나타났 다. Yoon과 $\mathrm{Yu}(36)$ 는 $S$. thermophilus의 생육촉진에 가장 큰 역할을 하는 유리아미노산은 glutamic acid라고 보고하

Table 3. Contents of free amino acids according to lactic acid bacteria fermentation of $C$. militaris grown upon T. molitor

\begin{tabular}{ccccc}
\hline Components & $\mathrm{NP}^{1)}$ & $\mathrm{FP}$ & T-value & P-value \\
\hline Aspartic acid & $1,205.16 \pm 5.84^{2)}$ & $1,047.82 \pm 3.07$ & $41.305^{* * * 5)}$ & 0.000 \\
Serine & $761.78 \pm 0.77$ & $662.34 \pm 5.35$ & $31.865^{* * * *}$ & 0.000 \\
Taurine & $169.63 \pm 1.12$ & $152.05 \pm 1.74$ & $0.581^{* * * *}$ & 0.000 \\
Glutamic acid & $2,059.97 \pm 1.00$ & $1,922.64 \pm 0.99$ & $0.989^{* * * *}$ & 0.000 \\
Glycine & $243.31 \pm 0.14$ & $248.74 \pm 0.08$ & $0.498^{* * * *}$ & 0.000 \\
Histidine & $215.64 \pm 0.15$ & $228.63 \pm 0.47$ & $0.264^{* * * *}$ & 0.000 \\
Arginine & $447.23 \pm 0.44$ & $349.37 \pm 0.04$ & $0.144^{* * * *}$ & 0.000 \\
Threonine & $644.04 \pm 0.24$ & $608.06 \pm 0.19$ & $0.760^{* * * *}$ & 0.000 \\
Alanine & $1,140.99 \pm 1.33$ & $1,069.98 \pm 0.71$ & $0.457^{* * * *}$ & 0.000 \\
Proline & $410.81 \pm 0.51$ & $430.37 \pm 0.01$ & $0.121^{* * * *}$ & 0.000 \\
Tyrosine & $356.42 \pm 0.01$ & $145.44 \pm 0.03$ & $0.275^{* * * *}$ & 0.000 \\
Cystine & $49.10 \pm 0.80$ & $61.66 \pm 0.10$ & $0.157^{* * * *}$ & 0.000 \\
Valine & $596.22 \pm 0.25$ & $568.30 \pm 1.70$ & $0.167^{* * * *}$ & 0.000 \\
Methionine & $124.33 \pm 0.97$ & $108.06 \pm 3.88$ & $0.219^{* * * *}$ & 0.002 \\
Lysine & $613.27 \pm 1.51$ & $621.15 \pm 0.80$ & $0.453^{* * * *}$ & 0.001 \\
Isoleucine & $247.22 \pm 3.02$ & $236.39 \pm 0.44$ & $0.166^{* * * *}$ & 0.004 \\
Leucine & $406.63 \pm 0.11$ & $393.00 \pm 3.40$ & $0.125^{* * * *}$ & 0.002 \\
Tryptophane & $199.14 \pm 0.07$ & $321.39 \pm 0.04$ & $0.498^{* * * *}$ & 0.000 \\
Phenylalanine & $330.15 \pm 0.01$ & $283.30 \pm 1.03$ & $0.119^{* * * *}$ & 0.000 \\
\hline TAA & $10,221.02$ & $9,458.66$ & & \\
\hline EAA $A^{3)}$ & $2,714.64$ & $2,581.85$ & & \\
\hline
\end{tabular}

${ }^{11} \mathrm{NP}$, non-fermented product; FP, fermented product.

${ }^{2)}$ All values are mean $\pm \mathrm{SD}$

${ }^{3)}$ Total free amino acid.

${ }^{4}$ Essential amino acid(Thr+Val+Met+Ile+Leu+Phe+Lys+Typ).

$5)^{* * * *} \mathrm{p}<0.005$.
여 본 연구와 일치하는 경향을 나타내었으나 물 추출물과 유산균 발효물의 유리아미노산 함량은 발효에 따른 유산균 의 자화능력과 발효환경 및 발효조건에 의한 차이로 판단된 다.

\section{Cordycepin}

갈색거저리 동충하초 물 추출물의 유산균 발효 전후의 cordycepin 함량 변화를 HPLC로 분석한 결과는 Table 4와 같다. 갈색거저리 동충하초의 cordycepin 함량은 물 추출물 이 $7.02 \mathrm{mg} \%$, 유산균 발효물이 $8.66 \mathrm{mg} \%$ 로 나타나 발효 후 cordycepin 함량이 증가하였다. Kim (27)은 cordycepin 함량 변화가 발효가 진행됨에 따라 함량이 증가하는 것으로 보고하였으며, 본 연구의 S. thermophilus KCCM 3782 균주 발효에 있어서 cordycepin 생성에 기여하는 발효 대사 작용 에 의해 cordycepin 함량이 증가한 것으로 추정되나 정확히 어떠한 발효 대사 작용에 의한 차이 인지 추가 확인이 필요 할 것으로 사료된다.

Table 4. Contents of Cordycepin according to lactic acid bacteria fermentation of $C$. militaris grown upon $T$. molitor

\begin{tabular}{cc} 
& \\
\hline sample & Cordycepin \\
\hline $\mathrm{NP}^{1)}$ & $7.02 \pm 0.19^{2)}$ \\
$\mathrm{FP}$ & $8.66 \pm 0.32$ \\
T-value & $-7.494^{* * * 3)}$ \\
P-value & 0.002 \\
\hline
\end{tabular}

\footnotetext{
${ }^{1)} \mathrm{NP}$, non-fermented product; FP, fermented product.

${ }^{2)}$ All values are mean $\pm \mathrm{SD}$ $\mathrm{p}<0.005$.
}

색 도

갈색거저리 동충하초 열수 추출물의 발효 전후에 따른 시료의 색도를 측정한 결과는 Table 5 와 같다. 적색도를 나타내는 a 값은 물 추출물 66.72, 유산균 발효물 149.92로 발효를 통해 a 값이 높아진 것을 확인하였고, 색의 명도를

Table 5. The Hunter's color value according to lactic acid bacteria fermentation of $C$. militaris grown upon $T$. molitor

\begin{tabular}{cccc}
\hline \multirow{2}{*}{ sample } & \multicolumn{3}{c}{ Hunter color } \\
\cline { 2 - 4 } & $\mathrm{L}$ & $\mathrm{a}$ & $\mathrm{b}$ \\
\hline $\mathrm{NP}^{1)}$ & $15.79 \pm 0.00^{2)}$ & $66.72 \pm 0.00$ & $54.45 \pm 0.06$ \\
$\mathrm{FP}$ & $-15.75 \pm 0.00$ & $149.92 \pm 0.00$ & $0.01 \pm 0.00$ \\
T-value & $-3)$ & - & $\left.1,633.300^{* * * 4}\right)$ \\
P-value & - & - & 0.000 \\
\hline
\end{tabular}

\footnotetext{
${ }^{1)} \mathrm{NP}$, non-fermented product; FP, fermented product.

${ }^{2)}$ All values are mean $\pm \mathrm{SD}$.

${ }^{3)}$ Not significant different.

$\mathrm{p}<0.005$.
} 
나타내는 L 값은 물 추출물과 유산균 발효물 각각 15.79 , -15.75 황색도를 나타내는 b 값은 $54.45,0.01$ 로 유산균 발효 물이 물 추출물 보다 낮은 것으로 나타났다. 이러한 결과는 발효과정에서 생성된 부산물과 성분 조성의 변화로 인한 차이로 판단된다.

\section{유산균 발효 전·후 생리활성 비교}

갈색거저리 동충하초 물 추출물의 유산균 발효 전후 $\mathrm{DPPH}$ 자유 라디칼 소거 활성을 측정한 결과는 Fig. $3 \mathrm{~A}$ 와 같다. 동충하초 열수 추출물의 발효에 따른 항산화 활성을 측정하기 위하여 시료구의 상등액을 취하여 $\mathrm{DPPH}$ 자유 라디칼 소거 활성을 측정하였다. 물 추출물과 유산균 발효 물의 $\mathrm{DPPH}$ 자유 라디칼 소거 활성은 유산균 발효물이 $91.92 \mathrm{EDA} \%$ 로 물 추출물의 $84.69 \mathrm{EDA} \%$ 보다 더 높게 나타 났다. $\mathrm{Bae}$ 와 $\mathrm{Ye}(37)$ 의 보고에 의하면 뽕잎차를 발효시켜 $\mathrm{DPPH}$ 자유 라디칼 소거 활성을 측정한 결과 발효물의 활성 이 더 높게 나타났으며 본 연구의 물 추출물과 유산균 발효 물의 DPPH 자유 라디칼 소거 활성과 유사한 경향을 나타내 었다.
갈색거저리 동충하초 물 추출물의 유산균 발효에 따른 $\mathrm{ABTS}^{+}$자유 라디칼 소거 활성은 Fig. $3 \mathrm{~B}$ 와 같다. 갈색거저 리 동충하초 유산균 발효물은 $60.82 \mathrm{EDA} \%$ 로 나타났고 물 추출물 시료구는 $54.57 \mathrm{EDA} \%$ 로 나타났다. 유산균 발효물 이 물 추출물에 비해 $6.25 \mathrm{EDA} \%$ 가량 높았고 $\mathrm{DPPH}$ 자유 라디칼 소거 활성과 $\mathrm{ABTS}^{+}$자유 라디칼 소거 활성 측정 결과가 유사한 경향을 보였으며 발효로 인하여 갈색거저리 동충하초 물 추출물의 항산화 활성이 높아지는 것을 확인하 였다.

갈색거저리 동충하초 물 추출물의 유산균 발효 전후의 $\mathrm{SOD}$ 활성은 Fig. $3 \mathrm{C}$ 와 같다. SOD는 세포 속 환원산소종 ROS(reactive oxygen species)를 과산화수소로 촉매작용 하 여 전환시키는 항산화 효소 중의 하나이다(30). 유산균 발효 물이 $49.43 \%$ 로 물 추출물의 $46.67 \%$ 보다 $2.76 \%$ 가량 활성이 더 높게 나타났으며 이는 superoxide anion의 활성을 억제시 키는 유사활성도를 확인할 수 있었다. Song (38)등의 보고 에 따르면 Lactobacillus에 의하여 천마의 지표성분인 gastrodin이 발효 전 $146.63 \mathrm{ppm}$ 에서 발효 후 $166.26 \mathrm{ppm}$ 으 로 미량 증가하였다고 보고하였다. 본 연구 또한 발효를
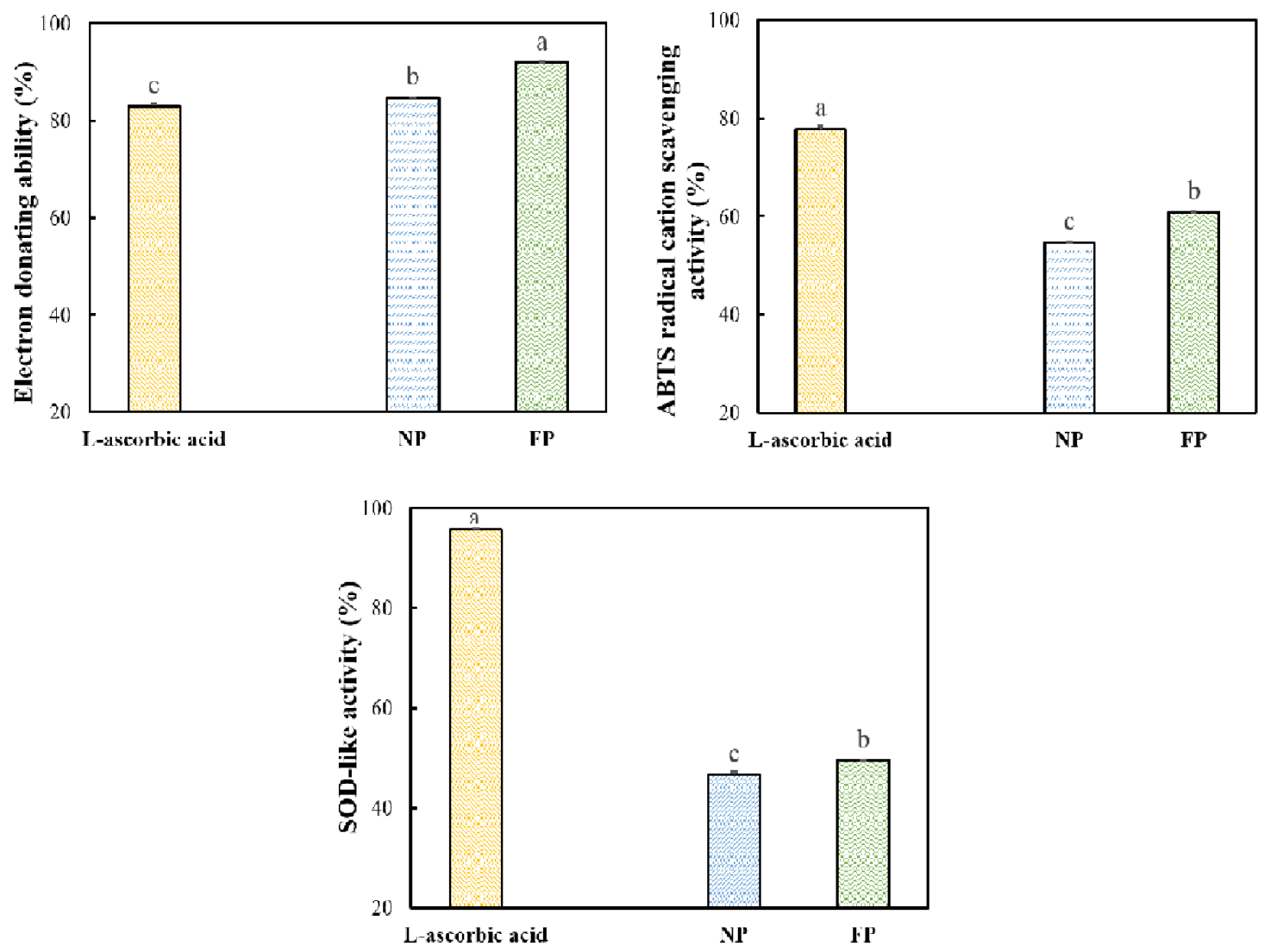

Fig. 3. Antioxidant activities before and after lactic acid bacteria fermentation of $C$. militaris grown upon $T$. molitor.

A, DPPH free radical scavenging ability of fermented water extract by lactic acid bacteria of Cordyceps militaris, B, ABTS radical scavenging ability of fermented water extracts by lactic acid bacteria of Cordyceps militaris. C, SOD activities of fermented water extracts by lactic acid bacteria of Cordyceps militaris.

$\mathrm{NP}$, non-fermented product; FP, Fermented product.

L-ascorbic acid $(10 \mathrm{ppm})$, All values are mean $\pm \mathrm{SD}$, Means in the same column followed by different uppercase letters are significantly different $(\mathrm{p}<0.05, \mathrm{a}>\mathrm{b}>\mathrm{c})$. 
통하여 동충하초 지표성분인 cordycepin이 증가하였으며 cordycepin의 함량에 의하여 항산화 활성이 증가한다는 연 구(33)를 미루어 보아 본 연구 또한 균주를 통한 발효로 cordycepin의 함량이 증가하여 항산화 활성이 높아진 것으 로 판단된다.

\section{요 약}

본 연구는 갈색거저리 동충하초 열수 추출물의 유산균 발효에 따른 항산화 활성에 대해 연구하였다. 갈색거저리 동충하초의 열수 추출물과 주정 농도별 추출물의 DPPH 자유 라디칼 소거 활성을 측정한 결과 열수 추출물이 74.81 $\mathrm{EDA} \%$ 로 가장 높았고 $80^{\circ} \mathrm{C}$ 에서 30 분 추출이 $76.49 \mathrm{EDA} \%$ 로 가장 높은 활성을 보였다. 7 가지 프로바이오틱스 유산균 주를 갈색거저리 동충하초 열수 추출물에 첨가하여 배양 시간별로 DPPH 자유 라디칼 소거 활성을 측정한 결과는 S. thermophilus 균주가 배양 6시간째 $80.01 \mathrm{EDA} \%$ 로 가장 높게 나타나 갈색거저리 동충하초 발효 우수 균주로 최종 선정하였다. 갈색 거저리 동충하초 열수 추출물의 유산균 발효 전 · 후 일반성분 조성 변화는 수분이 $85.27-68.54 \%$ 로 감소하였고, 조단백질은 $2.97 \rightarrow 3.56 \%$, 조지방은 $0.32 \rightarrow$ $1.08 \%$ 로 증가하였다. 무기성분은 $\mathrm{K}$ 가 $5.92 \mathrm{mg} \%$ 로 가장 높은 함량을 보였고, $\mathrm{Na}, \mathrm{Mg}, \mathrm{Ca}$ 및 $\mathrm{Zn}$ 모두 발효 후 증가하 였으며, 총 유리아미노산 함량은 물 추출물 $10,221.02 \mathrm{mg} \%$, 유산균 발효물 9,458.66 mg\%로 물 추출물의 함량이 더 높게 나타났다. 갈색거저리 동충하초의 지표물질로 알려진 cordycepin은 발효를 통해 $7.02 \mathrm{mg} \%$ 에서 $8.66 \mathrm{mg} \%$ 로 증가 하였다. 발효 전 - 후에 따른 색도를 측정한 결과 발효 후 $\mathrm{a}$ 값은 $66.72 \rightarrow 149.92$ 로 증가 하였고, $\mathrm{L}$ 값과 $\mathrm{b}$ 값은 각각 $15.79 \rightarrow-15.75,54.45 \rightarrow 0.01$ 로 발효 후 감소하였다. 갈색거 저리 동충하초 열수 추출물의 유산균 발효에 따른 DPPH 자유라디칼 소거능을 측정한 결과 발효 전 $84.69 \mathrm{EDA} \%$ 에 서 발효 후 $91.92 \mathrm{EDA} \%$ 로 증가 하였으며, $\mathrm{ABTS}^{+}$자유 라디칼 소거 활성과 SOD 활성 또한 발효 후 증가하는 것을 확인하였다.

\section{감사의 글}

이 논문은 2017년 순천대학교 학술연구비(과제번호: 2017-0162) 공모과제로 연구되었음.

\section{References}

1. World Health Organization: Regional Office for Europe. http://www.euro.who.int/en/what-we-do/healthtopics/no ncommunicable-diseases/obesity/facts-and-figures (accessed December 2013)

2. Jeonnam Agricultural Reserch \& Extension Services (2015) Development of feed additives for poultry with insects. Rural Development Administration, Naju, Korea, p 61-67

3. Ramos-Elorduy J, Pino MJM (1990) Caloric content of some edible insects of mexico. Reviews of Society Qim Mexico, 34, 56-68

4. Lee KH, Yoon YT, Park YI, Lee HJ, Jeong NY (2017) Quality evaluation of acorn Mook prepared with mealworm (Tenebrio molitor) powder. Korea J Food Sci Technol, 30, 1042-1047

5. Kim SH, Kim KB, Noh JS, Yun EY, Choi SK (2014) Quality characteristics of pasta with addition of mealworm (Tenebrio molitor). Food Serv Ind J, 10, 55-64

6. Park DG (2006) The quality properties of loaf bread with Cordyceps militaris powder. MS Thesis, Sunchon National University, Korea, p 3-4

7. Min KT, Kang MS, Kim MJ, Lee SH, Han JS, Kim AJ (2016) Manufacture and quality evaluation of cookies prepared with mealworm (Tenebrio molitor) powder. Korean J Food Nut, 29, 12-18

8. Kim HM, Kim JN, Kim JS, Jeong MY, Yun EY, Hwang JS, Kim AJ (2015) Quality characteristics of patty prepared with mealworm powder. Korean J Food Nut, 28, 813-820

9. Chung SJ, Lee YH, Chung JH, Lee BR, Han DM (1995) Antifungal effect and activity spectrum of crude antifungal proteins from hemolymph of larvae of Tenebrio molitor in Korea. Korean J Mycol, 23, 232-237

10. Lee HW, Jeong MJ, Mun MJ (1999) Morphological characteristics of superposition ommatidium in the mealworm beetle, Tenebrio molitor. Korean J Entomol, 29, 85-93

11. Lee JH, Kim NK, Lee DY, Lee CH (1999) Protective effect of selected amino acids and food extracts on ethanol toxicity decrement in rat liver. Korean J Food Sci Technol, 31, 802-808

12. Kim SH, Shon JY, Park JS, Kim JW, Kang JH, Yun EY, Hwang JS, Kim HM (2016) Change in dietary intake and nutritional status using mealworms as hospital meal in postoperative patients. J Korean Diet Assoc, 22, 292-309

13. Lee JD (1998) Mycology $3^{\text {rd }}$ ed, Guduck publishing Co 14. Jo SY (2000) Healthy longevity silkworm Cordyceps. 
Shinil Corporation, Seoul, Korea, p 3-11

15. Sung JM (1996) Korea Cordyceps. Kyohaksa, Seoul, Korea, p 10-15

16. Kim AJ, Yuh CS, Bang IS (2007) A qualitative investigation of Dongchunghacho jelly with assorted increments of paecilomyces japonica powder. Korean J Food Nutr, 20, 40-46

17. Jo SY (2000) Effectiveness and utilization of silkworm Cordyceps. National Nutr, 4, 20

18. Han DS, Song HN, Kim SH (1999) Cordyceps: New functional food material. Food Science and Industry, 32, 56-63

19. Kim JA (2007) Quality characteristics of jelly prepared with cordyceps powder. Korean Soc Food Nutr, 20, 40-46

20. Bang HY, Park MH, Kim GH (2004) Quality characteristics of Kochujang prepared with Paecilomyces japonica from silkworm. Korean J Food Sci Technol, $36,44-49$

21. Park WH (2009) Quality properties of herbal vinegar using medicinal herbs fermented with Cordyceps militaris. MS Thesis, Sunchon National University, Korea, p 1-4

22. Park KY (2012) Increased health functionality of fermented foods. Food Industry and Nutrition, 17, 1-8

23. Park MS, Ji GE (2014) Development of probiotics and industrialization. Food Science and Industry, 47, 19-28

24. AOAC (1995) Official methods of analysis $16^{\text {th }}$ ed, Association of official analytical chemists, Washington DC, USA, p 7-10

25. KFDA (2007) Test method in general. Int'l Food code (separate volume), Korea food and drug administration, Cheongju, Korea, p 1267

26. Ohara I, Ariyoshi S (1979) Comparison of protein precipitants for the determination of free amino acid in plasma. Agric Biol Chem, 43, 1473-1478

27. Kim JM (2007) Separation \& analysis of cordycepin in Cordyceps militaris and Its optimization of cordycepin production. MS Thesis, Dongguk University, Korea, p 11-14

28. Abe N, Nemoto A, Tsuchiya Y, Hojo H, Hirota A (2000) Studies on the 1.1-diphenyl-2-picrylhydrazyl radical scavenging mechanism for a 2-pyrone compound. Biosci Biotechnol Biochem, 64, 306-313

29. Re R, Pellegrini N, Proteggente A, Pannala A, Yang M, Rice-Evans C (1999) Antioxidant activity applying an improved ABTS radical cation decolorization assay. Free Radical Biol Med, 26, 1231-1237

30. Marklund S, Marklund G (1974) Involvement of superoxide anion radical in the autoxidation of pyrogallol and a convernient assay for superoxide dismutase. Eur J Bio, 47, 469-474

31. Dong S (2004) Physiological activities of clove by the different extraction solvents. MS Thesis, Hankyong University, Korea, p 1-4

32. Ko WH, Hong JK, Lee SW, Cha JH, Cha JU, Baek HH, Park HJ (2012) The effects of coating treatments on enteric coating of the soft capsules containing omega-3 fatty acids. Korean J Food Sci Technol, 44, 168-172

33. Ahn HY, Park KR, Kim YR, Cha JY, Cho YS (2013) Chemical characteristics in fermented cordycepin-enriched Cordyceps militaris. J Life Sci, 23, 1032-1040

34. Choi OJ, Choi KH (2003) The physicochemical properties of Korean wild teas (green tea, semifermented11 tea, and black tea) according to degree of fermentation. J Korean Soc Food Sci Nutr, 32, 356-362

35. Kim JS (2009) Quality properties of white lotus leaf fermented by mycelial Paecilomyces japonica. J Korean Soc Food Sci Nutr, 38, 594-600

36. Yoon SS, Yu JH (1986) Identification of growth stimulatory compound in the mixed culture of Lactobacillus helveticus YM-1 and Streptococcus thermophilus CH-1 in milk. Korean J Food Sci Technol, 18, 492-496

37. Bae MJ, Ye EJ (2010) Antioxidant activity and in vitro for anticancer effects of manufactured fermented mulberry leaf tea. J Korean Soc Food Sci Nutr, 39, 796-804

38. Song HN, Park MS (2018) Analysis of biological activities and functional components in fermented Gastrodia elata blume by Lactobacillus. J Korean Soc Food Science and Nutrition, 47, 32-38 